\title{
NUTRITION AND METABOLISM
}

137

ZINC ABSORPIION IN AND DURING RECOVERY IRROM SIEVIERE MALNUTRITION IN CHILDHOOD. Barhara E Golden \& Michat HN Golden (spn.

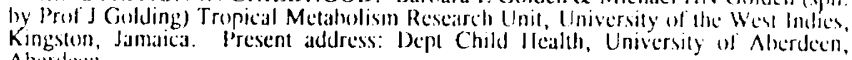
Nherdect

Severely malnourished Jamaican children have evidence of hoth malabsorption and aine (Zn) deficiency, especially when they are oedematous. However, on high conergy feeds, they are able wo gain weight at greatly accelerated rates. By labelling their feeds with

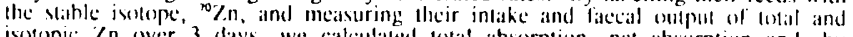
issotopic Zn over 3 days, we calculaled lotat absorption, net absorption ind, by

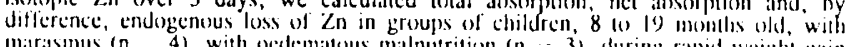

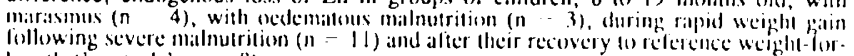
length ('controls', $n=8$ )

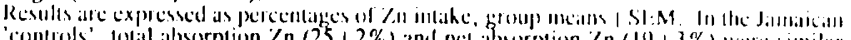

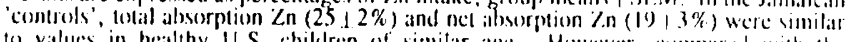
to values in healthy U.S. children of simitar age. However, comprared with the

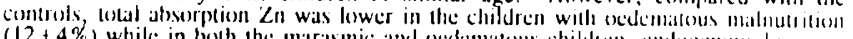

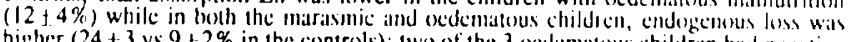
higher $(24+3$ vs $9+2 \%$ in the controls): two of the 3 oedematous children had nepative

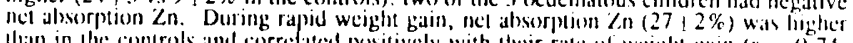
llian in the controls and corredated positively with their ralte of weighl gioin (1 0.74 $p<0.01)$ : their condogenous loss wis low $(5,2 \%)$

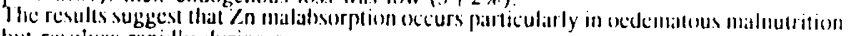
but resolves rapidly during recovery.

\section{0}

FIRST TRIMESTER PHENYLKETONURIA (PKU) DIETARY CONTROL AND NEURODEVELOPMENTAL OUTCOME IN INFAHTS. Ann Lorek, Jemy Haudan, Jan Towneend, Maggie Liburn, Ann Stewart and David Brenton. Depte of Paediatric

To avold fotal damage in women with pKU, Btrict preconception and pregnancy control of blood phenylalanine concentrations (PHE) have been pregnancy control of blood phenylalanine concentrations (PHE) have been recommended (1). To find out if these recommendations prevented infonts from 23 we etudied the neurodevelopmental outcome of 24 infants from 23 pregnancies in which strict dietary control was introduced prlor to conception. 18 had reached 1 year. Measures of outcome were related to mean PHE, and to number of day PHE exceeded $300 \mu \mathrm{mol} / \mathrm{l}$ in the firat trimester. They included head circumference
$(\mathrm{OFC})$ and neurological examination at term and 1 year and developmental (OFC) and neurological examination at term and 1 year and developmental quotient (Grifflthe GQ) at 1 year. The ofC atandard deviation ocores 496) $\mu$ mol/l were igniflcantly amaller than those with mean PHE of $<300$ $(139-281) \mu \mathrm{mol} / 1$ (p<0.05). Within the group with mean PHE $<300 \mu \mathrm{mol} / 1$, OFC SDS was lower in those whose PHE exceeded $300 \mu \mathrm{mol} / 1$ for more than 10 days $(p<0.05) .17$ of the 24 infants examined at term, and 13 of the 18 at 1 year, had abnormal nourological gign日. The mean 60 of the 18 infante was $109+13$ and did not differ according to PHE we conclude that a) mean $\mathrm{PHE}$ of $<300 \mu \mathrm{mol} / 1$ in the ftret trimegter improves head growt h especially when control is etrict bl gtrict control thi

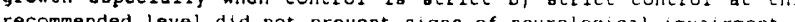
1. MRC Working Party on PKU. Arch Dis Child $1993 ; 68: 426-427$.

\section{8}

EVALUATION OF THE BODY COMPOSITION AND THE BONE MINERAL CONTENT BY DUAL $X$ RAY ABSORPTIOMETRY. A. LAPILLONNE*, B.L.SALLE*, P.BRAILLONS, M.CIIAMBON*. Deparment of Neonatology* and Rhumatology§ Ilopital Edouarú Hertiol, LYON, FRANCE

An I lologic QDR $1000 \mathrm{~W}$ system equiped with a special pediatric scanming program was used to evaluate total bone mineral content (BMCl), lean body mass and $f_{3}$ content. 65 infants were studied, gestational age ranged from 36 to 40 wecks: 28 were appropriate for gestational age ( $\mathrm{AGA}), 24$ were sniall for gestational age (SGA) and

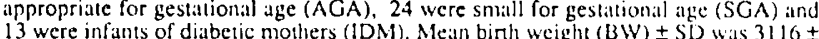
$557,2015 \pm 184$ and $3601 \pm 535$ grams; mean length \pm SD wils $492 \pm 2.5116 \pm$ $557,2015 \pm 184$ and $3601 \pm 535$ grams : mean length $\pm S D$ wils $49.2 \pm 2.5,4.4 .8 \pm$
1.9 and $49.8 \pm 2.9 \mathrm{~cm}$ respectively. The scial was performed during the lirst diry of life. $\mathrm{BMCl}$ (grams of hydroxyapatite), lean body mass (grams), fat content (grams), \% life. BMCt (grams of hydroxyapatite), lean body mass (grams), fat content (
BMCt \% fat and \% lean mass were (results were expressed as mean \pm SD)

$B M t_{1} \%$ fit and \% lean mass were (results were expressed as mean \pm SD) :

\begin{tabular}{|c|c|c|c|}
\hline & $\wedge G A(n=28)$ & $\operatorname{SGA}(n=24)$ & IDN $(n=13)$ \\
\hline BMCI, (grams) & $45.9 \pm 18.1$ & $24.9 \pm 9 \cdots$ & $68.3 \pm 21.7 \bullet$ \\
\hline (grams) & $457 \pm 148$ & $281 \pm 47 \cdots$ & $804 \pm 244^{\circ}$ \\
\hline Lean, (grams) & $2481 \pm 401$ & $1658 \pm 170 \cdots$ & $2545 \pm 444$ \\
\hline$\% \mathrm{BMCl}$ & $1.5 \pm 0.4$ & $0.5 \cdot$ & $1.9 \pm 0.6 \cdots$ \\
\hline$\%$ Fat & $15.0 \pm 2.7$ & $14.3 \pm 2.1$ & $22.7 \pm 4.9 \cdots$ \\
\hline \% Lean & $83.4 \pm 2.8$ & $80.8 \pm 17.6$ & $73.1 \pm 0 \cdots$ \\
\hline
\end{tabular}

In this gestational age range (36-40 weeks), 1) $B M C$ in $A G A$ group dilfered from both SGA and IDM ciltegories: BMCt wits beller correlated with birthweight than with gestational age. 2) Body composition in \% of BW did not differ significintly between SGA and $A G A$ infants. 3) In IDM infans, fat content increilsed and thus explained the heavy birthweight.

\section{9}

THE SERUM TRANSFERRIN RECEPTOR AS INDICATOR OF IRON DEFICIENCY IN INFANTS

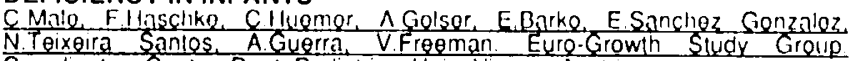
C. elxeira Sanios A.Guerra V.Freman. Euro-Grow

Objective: Serum transferrin receptor is now well established in adults as index of iron status tt increases with tissue iron need and is more sensitive than index parameters to mild iron deficiency. The purpose of this study was to test its
value in infants, a population especially susceptible to iron deficiency.

value in infants, a population especially susceplible to iron deficiency.
Methods and setting: We measured hemoglobin, serum ferritin (RIAgnost, Behring) and the serum transferrin receptor (CLINIGEN EIA Amgen Behring) and the serum transferrin receptor (CLINIGEN EIA. Amgen
Diagnostics) in 71 healthy infants at 12 months of age from 5 centers of the Diagnostics) in 71 healthy infants at 12 months of age from 5 centers
Euro-Growth Study (Vienna. Salzburg, Budapest, Bilbao, Porto. Dublin). Euro-Growth Study (Vienna, Salzburg, Budapest, Bilbao, Porto, Dublin). Results: Intra- and interassay variances of the transferrin receptor (TfR)
measurements were $3.5 \%$ and $7.75 \%$, respectively. Infants with hemoglobin $(\mathrm{Hb})$ levels $<11 \mathrm{~g} / \mathrm{dl}$, indicating anemia, had significantly higher TtR values than infants with $\mathrm{Hb}$ values $>11 \mathrm{~g} / \mathrm{dl}(3,46 \pm 0.99$ vs $2.66 \pm 1.04 \mathrm{ug} / \mathrm{ml} ; p<0.05$. Wilcoxon rank test). In infants with $\mathrm{Hb}>11 \mathrm{~g} / \mathrm{dl}$ and $\mathrm{s}$-territin $<12$, between 12.20 , and $>20$ $\mathrm{ng} / \mathrm{ml}$, TiR values were $3.04 \pm 1.13^{*}, 2.54 \pm 0.93$ and $2.18 \pm 0.64^{\circ} \mathrm{ug} / \mathrm{ml}$, respectively (" $p<0.05$, Duncans Multiple Range test). Regression analysis did not reveal a negative correlation between TIR and either $\mathrm{Hb}$ or $\mathrm{s}$-ferritin.

Conclusions: Serum transferrin receptor is significantly increased in infants with iron deficiency anemia. In inlants with no anemia $(\mathrm{Hb}>11 \mathrm{~g} / \mathrm{dl})$ but low iron stores (s-territin < 20 ) elevated transferrin receptor values already indicate iron deficient erythropoeisis. Although our data are limited the combination of serum ferritin and serum transterrin receptor appears promising as a screening tool for mild iron deficiency in infants.

\section{1}

PROTEIN METABOLISM IN VENTILATED PRETERM INFANTS ON THE FIRST DAY OF LIFE.

J.B. Van Goudoever, J.L.D. Wattimena, P.J.J. Sauer. Department of Pediatrics, Sophia Childrens Hospital, Erasmus University Rotterdam, The Netherlands.

Protein kinetics were measured to examine the effect of immediate commencement of amino acid (AA) administration following birth. Eight infants (birth wt $1.5 \pm 0.3 \mathrm{~kg}$ ) received exclusively $6.6 \pm 1.4 \mathrm{~g}$ glucose $/ \mathrm{kg} / \mathrm{d}(26 \mathrm{kcal} / \mathrm{kg} / \mathrm{d})$ and seven infants (bw $1.4 \pm 0.4 \mathrm{~kg}$ ) received $5.9 \pm 2.0 \mathrm{~g}$ giucose $/ \mathrm{kg} / \mathrm{d}$ and $1.2 \pm 0$. $\mathrm{g} \mathrm{AA} / \mathrm{kg} / \mathrm{d}(28 \mathrm{kcal} / \mathrm{kg} / \mathrm{d})$. All infants were ventilated and studied at the first day of life. A primed continuous infusion of $\mathrm{NaH}^{13} \mathrm{CO}_{3}$ was followed by a primed continuous infusion of $\left[1{ }^{13} \mathrm{C}\right]$ leucine. Isotopic enrichment of expired $\mathrm{CO}_{2}$ was measured by IRMS and dilution of ${ }^{13} \mathrm{C}$-KIC was measured by GCMS. Nitrogen excretion was measured in urine. The results (mean $\pm S D$, $\dagger$ signediff. at $p \leq 0.01$ ): $\mathrm{N}$-balance Turnover Oxidation Synthesis Breakdown Balance $\mathrm{mg} / \mathrm{kg} / \mathrm{d}$ $\mu \mathrm{mol}$ leucine $/ \mathrm{kg} / \mathrm{hr}$

glucose $\quad-110 \pm 47201 \pm 20 \quad 41 \pm 13 \quad 160 \pm 20 \quad 186 \pm 20 \quad-27 \pm 13$ glu $+\mathrm{AA}+45 \pm 98+219 \pm 33 \quad 48 \pm 16 \quad 171 \pm 35 \quad 171 \pm 35+4 \pm 17 \dagger$ Cenclusions: 1. Amino acid administration does not significantly alter leucine oxidation on the first day of life. 2. Even at a very low energy intake, amino acid administration of $1.2 \mathrm{~g} / \mathrm{kg} / \mathrm{d}$ prevents both negative leucine and nitrogen balances. Based upon protein balances, it seems that the administration of amino acids on the first day of life is benificial for preterm infants

\section{2}

MIXED MCT/LCT LIPID EMULSION USE IN SICK VLBW INFANTS David C Wilson, Henry L llalliday, Mark Reid, Garth Mcclure, John A Dodge. Department of Child Health, The Queen's University of Belfast and Royal Maternity Hospital, Belfast.

Undernutrition is common in sick VLBW infants requiring parenteral nutrition (PN). Lipid-free PN leads to poor energy intake but lipid has been associated with increased incidences of infection and BPD. Medium chain

triglycerides (MCT) are metabolised faster than long chain (LCT). We therefore designed a new PN regimen, with use (LCT). We therefore designed a new PN regimen, with use of a 50 MCT emulsion from day 2 and in greater amounts, and compared this to a conventional PN regimen with 1008 new PN regimen (MCT) or control (LCT) groups: Lipofund in MCT/LCT (B Braun) was used in the MCT group $(n=64)$ and Intralipid (Kabi vitrum) in the LCT group $(n=61)$. The MCT group had a mean BW of $925 \mathrm{~g}$ compared to $933 \mathrm{~g}$ in the LCT group. Mean energy intakes whilst receiving $\mathrm{PN}$ were greater $(p<0.001)$ in the MCT group at days $7,14,21,28,35$ and 42 . The incidences of BPD were 29 in the MCT group and 298 in the LCT group (ns), with infection rates of 638 and 748 respectively (ns). There were no significant increases in incidences of hyperlipidaemia or hyperketonaemia in the MCT group. We conclude that liberal MCT emulsion usage lessens undernutrition without adverse clinical or metabolic sequelae in sick preterms. 